An excellent French translation was published by Charles Daremberg (1854-56), but it has been known for several years that Mrs M. T. May was preparing an English version. This wait has now been handsomely rewarded. Mrs May has used the critical edition of the Greek text of De Usu Partium made by Georg Helmreich and published as a Teubner text in 1907. She has tried to avoid being too literal or too free in her translation and in this she has achieved commendable success. It is accurate, readily comprehensible, eminently readable, and fully documented with footnotes, both explanatory and philological.

In the introductory chapters contained in the first volume, Mrs May first describes the history of the Latin text and then discusses in general the contents and purpose of the treatise. There are also excellent chapters dealing with the knowledge of anatomy before the time of Galen, with Galen's contribution to anatomy and, finally, with his system of physiology. These alone are scholarly and important contributions to Galenic studies. They are brief and well documented (251 footnotes) and they can be strongly recommended as introductions to Galen as a medical scientist for students; the only criticism is that the references are at the end of volume two. Together with these references there is an excellent index and, as Daremberg's edition has none, this will be a boon to readers.

Mrs May has spent many years working on this outstanding book, but her extended labours will without doubt be rewarded by the praise and gratitude of generations of scholars and students. EDWIN CLARKE

\section{RELICS OF ANCIENT MAN}

\section{The Archaeology of Early Man}

By J. M. Coles and E. S. Higgs. Pp. 454+12 plates. (Faber: London, July 1969.) $150 s$.

The purpose of this book is "to describe the evidence for some aspects of human behaviour over the greater part of the past three million years". It seeks to do so on a regional basis, with nine chapters devoted to parts of Africa, three to Europe, five to Asia (including Russia and the Middle East), and three to the Americas, Australia and New Zealand. The last are so abbreviated as to be quite useless. In each chapter the treatment is initially general and along broadly chronological lines, followed by a brief synopsis of the successions and artefactual inventories of selected sites. These chapters are preceded by brief, often very provincial chapters on Pleistocene chronology, flora and fauna, and by a chapter, which is essentially illustrated, on the technological and typological aspects of stone artefacts.

The aim of the book is laudable, but unfortunately every chapter is a disappointment. There are innumerable errors. A specialist vocabulary is used throughout with no attempt at a glossary nor even a measure of explanation. There is a lamentable absence of tables or charts (although there is no shortage of text figures) to assist the reader with regional successions or site stratigraphies. There is rank confusion in the use and application of terms for palaeocultural phenomena. There is nearly complete lack of discussion and illustration of the ecological approach to studies of early man. There is no explication nor adequate illustration of schomes designed to system. atize the technological and typological aspects of artefacts in stone and other raw materials. And there is no information on analytical approaches and procedures.

Studies of early man have changed markedly in the past decade or so, in relationships with other disciplines, in their procedures, in their intent, and in their theoretical aspects. None of these advances is reflected here, where human behaviour is scarcely evident behind the dry relics of ancient man's restless hands. F. Clark HowelL

\section{MEMBRANE PHENOMENA}

\section{Biological Interfaces}

Flows and Exchanges. (Proceedings of a Symposium sponsored by the New York Heart Association.) Pp. 326. (Little and Brown: Boston; Churchill: London, 1968.) 65.

Altнолgн without too much contrivance much of modern biology could be included under the title of this book, most of the symposium it records is devoted to nembrane phenomena in a narrower sense. The symposium falls into four sections, three concerned with the properties of membranes at a subcellular level and one with a higher level of complexity, namely exchanges across the capillary wall.

The section on blood capillaries opens the book and includes chapters on transcapillary exchange by Wieder. hielm and Renkin and one on the ultrastructural basis of these exchanges by Karnovsky. The two central sections are devoted to model systems, the first mostly about black lipid membranes, their formation, optical, electrical and permeability properties (Tien, Finkelstein and Cass) and, as a foil to these chapters stressing the similarity of the models with membranes, it is well to be rominded of one of the chief differences between them and eell membranes in an account by Rand of the viscoelastic properties of the red cell surface. In the following section on monolayers, a chapter by Miller deals with the physical aspects of ion movement across monolayers; Blank draws attention to the value of monolayers as biological models, and their biological relevance is further illustrated in Salton's discussion of the effects of lytic agents on cells. The closing section, which in common with other sections includes both structural and functional aspects, returns from models to cells. Korn briefly reviews current concepts of membrane structure, various aspects of the recent biochernical analysis of transport in bacteria are discussed by Pardee and the amenability of these cells to direct analysis is interestingly compared with the apparently more intractable red cell by the juxtapositicn of an account of the investigation of glucose transport into mammalian cells.

Speakers at such symposia are faced with the dilemma of whether to direct their remarks towards those participants already familiar with their particular aspect of the symposium or whether to address the meeting as a whole at the possible risk of boring their immediate colleagues. The choice the speaker makes is not irremediable at the meeting, for personal contact is easy. The reader of the published proceedings does not have this advantage, however, and the speaker's attitude becomes more critical. In the present instance the balance is on the whole a happy one and readers can glean some insight into the present status of four aspects of membrane study.

The book is well produced and reasonably priced, yet private buyers may be deterred from buying it as the subject matter is necessarily ephemeral and, in the nature of a general symposium, no aspect is comprehensively covered. It could be a valuable addition to libraries, but those subseribing to the Journal of General Physiology will already possess these proceedings in the form of a supplement to Volume 52.

A. H. MADDY

\section{DRUG DETOXICATION}

\section{Microsomes and Drug Oxidations}

Edited by James R. Gillette, Allan H. Conney, George J. Cosmides, Ronald W. Estabrook, James R. Fouts and Gilbert J. Mannering. (Symposium on Microsomes and Drug Oxidations held at Bethesda, Maryland, February 16-17, 1968.) Pp. xiv +547. (Academic Press: London and New York, May 1969.) 112s.

THE six editors of Microsomes and Drug Oxidations represent a fair cross-scction of the fifty-two experts 